\title{
Characteristic Solar Tree Construction on Solar Panel Power Plant
}

\author{
Syafriyudin \\ Departement Electrical Engineering \\ Institut Sains dan Teknologi AKPRIND Yogyakarta \\ Yogyakarta, Semarang \\ ddien@akprind.ac.id.
}

\begin{abstract}
Every year the population in Indonesia is increasing so that the electricity needs needed will also be greater. Considering that environmentally friendly electrical energy generation is needed, solar cells are the right choice. Today many have used and developed solar cells as PLTS (Solar Power Plants). Solar cells are widely applied to calculators, powerbanks, street lights, surveillance cameras, traffic lights and so on. But in the design of this solar cell application, development is still needed so that the results are more effective. Solar tree is a Solar Power Plants that combines solar panels with construction like a tree. The solar panel is placed in a design like leaves on tree branches. With the solar tree design, it is expected that the solar panel can capture greater sunlight intensity, both in the morning, during the day, and in the afternoon. This Solar Power Plants uses solar panels with a maximum power of $10 \mathrm{WP}$ (Watt-Peak) of 6 units. With panel 1, panel 2, and panel 6 where the position tends to the east so that this panel can work better in the morning until noon. While panel 3, panel 4, and panel 5 work better during the day until late afternoon because they are more inclined to facing west.
\end{abstract}

Keywords—solar cell; Solar tree; photovoltaic; solar power plant

\section{INTRODUCTION}

Electrical energy is an energy that is needed by all humanity. Considering that in 2018 there are so many technologies that are increasingly advanced and continue to develop, especially in the electronic field. For example are cell phones, laptops, computers, televisions and others that require a supply of electrical energy sources. Especially people in Indonesia, many now use electronic equipment which of course will have an impact on the large amount of electricity needs. The increasing need for electrical energy must also be followed by additional power plants. The more power plants that use fossil energy as fuel, it will cause more pollution that can damage the environment around us. Besides that, the source of electricity from non-renewable energy (coal, natural gas, geothermal) will eventually run out. Therefore, it is necessary to study the electricity generation from renewable natural resources which will be very important for humans in the present and in the future.

\section{Solar Light Radiation Energy.}

Solar energy is all the energy that can reach the earth coming from the sun. Solar energy is divided into 2, namely solar heating and solar electricity. These two energies have different meanings and require different tools to convert them.

a. Solar Heating

Solar heating is the effect of heat from sunlight reaching the earth. This heat effect of the sun's light was used thousands of years ago. Examples of its use are to dry clothes, make salt from sea water, dry cement in buildings and many other applications.

\section{b. Solar Electricity}

Solar electricity is usually called solar energy. This energy will be converted into electrical energy by using a device called solar cells/photovoltaic cells. The word "photovoltaic" returns to the voltage caused by light (photons) [6].

Electricity supply has gained importance with the increase of electricity demand in the world. The energy that the sun can accept forever provides great convenience for electricity generation. In regions where the sun's rays are steep, it is easier to generate electricity from the solar energy, whereas in regions where the sun's rays are horizontal, the electricity production from the solar energy remains at a lower level. In this study, Istanbul and Adana are compared in the northern and southern regions of Turkey. These two cities were examined for daily sunshine periods, daily and monthly radiation amounts. The effects of air temperatures and sunshine durations on the average radiation amounts have been investigated. The province of Adana has an annual total of $1568.49 \mathrm{kWh}$, whereas the province of Istanbul has a total of $1327 \mathrm{kWh}$ radiation. When the annual sunshine periods are examined, it is 97.13 hours in Adana and 78.99 hours in Istanbul. It is seen that less electricity production can be done year round in Istanbul province and the hourly production is more than that in Adana when compared to sunrise times. When the average annual temperatures are examined, Adana province is $19^{\circ} \mathrm{C}$ and Istanbul province is $13.8^{\circ} \mathrm{C}$. Although the province of Istanbul has a lower average temperature, it has been found that it has a higher yield than the province of Adana [2]. The radiation energy of the sun's light itself will be absorbed and also reflected back before reaching the earth. Objects such as the ozone layer, clouds, dust and gas particles, water droplets will absorb the sun's light. Even when it reaches the earth, some of this solar energy will be absorbed by the earth and reflected back into the air. 


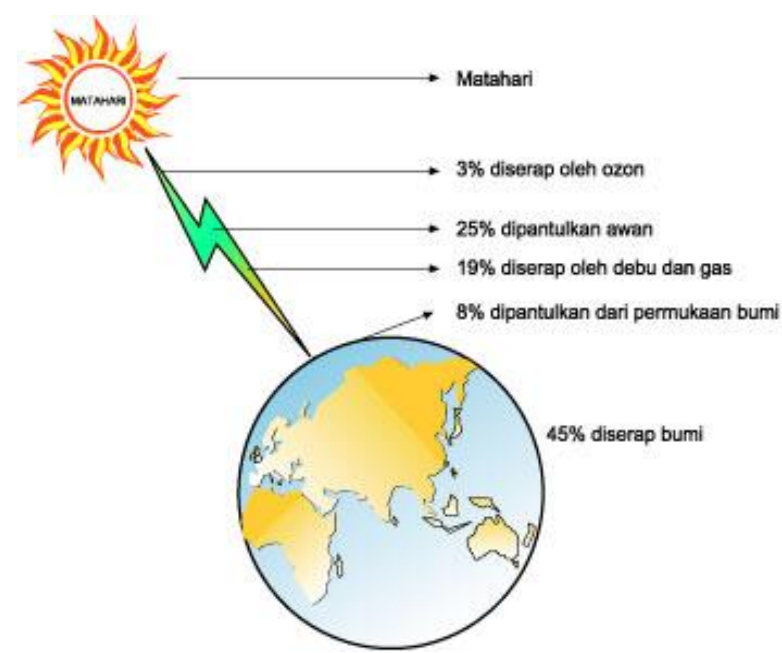

Fig. 1. Scheme of absorption and reflection of sunlight

Many things can affect the output power of the solar panel. The factors that can affect this power are the angle of the solar panel, the height of the place, the intensity of the sun, and the type of panel used. And from the research conducted on the slope of the solar panel, it was found that the maximum value of the output power of the solar panel was between the angle 0 ${ }^{\circ}-30^{\circ}[11]$.

The intensity of light entering the solar cell changes every time, generally the light intensity in the morning and evening is low. The maximum light intensity for the morning (before 8 ) is 12,240 lux while the afternoon (after 5 a clock) is 7,940 lux. And reaches its peak during the day with a maximum light intensity of 123,200 lux (12:01:00 PM).[1]

Flat or roof top mountings of PV systems require large area or land. Scarcity of land is greatest problem in cities and even in villages in India. Solar Power Tree provides better alternative to flat mounting of PV systems. For domestic lighting and other applications use of Solar Tree is more relevant when PV system is to be used. In this article load or energy requirement of small house in India is estimated to $1.75 \mathrm{kWhr} /$ day. All the calculations are done considering solar radiation data at Kolhapur, Maharashtra (16.760). The load capacities or sizes of all other components of system are determined. Tracking system can be easily employed in Solar Tree hence its performance is better than flat mountings of solar PV system. The overall cost can be reduced using simple and innovative designs of Solar Tree. The total cost of Solar Tree is about Rs.60000 /- and payback period is estimated to 10 years [4]

While the research conducted by Pangestuningtyas D.L. shows that in the installation of solar panels the fixed array type has an angle range between $1^{\circ}$ to $34^{\circ}$. The angle of the slope of the solar panel in the rainy season is $1^{\circ}$ degree. Whereas in the summer, the slope of the solar panel is $24^{\circ}$. This is due to the daily and annual false motions of the sun's orbitals on the earth. Sunlight is energy that will never run out. In addition this solar energy has no pollution and can be used as a source of electrical energy using solar cells. Many have done research on electricity generation with solar cells, but development is still needed so that electricity generation, solar cells can work optimally. Solar cells can work optimally if the radiant energy of sunlight hits the plane of the solar cell panel perpendicularly. Given that the sun is always rotating, the placement of solar cells must be studied gradually.[8]

This paper introduces a new solar technology that describe us how solar trees can able to convert sunlight into energy. Solar tree is producing solar energy and electricity, the panels which it contains is used to form a shape of tree and generates electricity. Now a days with the growing population and energy demand we should take a renewable option of energy source, which should not cause pollution and other natural hazards. In this case the solar energy is the best option for us. Hence, we can say that it is a revolutionary idea to bring the lighting concept in the urban and the rural areas in a populated country like INDIA and these technologies lead to the development of high efficiency solar energy [3].

Solar cells can be made from different materials, but the ones available generally still use silicon as the main ingredient. There are 3 types of solar cells that are currently widely used, namely amorphous silicon, monocrystalline silicon, and polycrystalline / multicrystalline silicon. Amorphous silicon is a type of solar cells commonly used in calculators and watches that can provide a source of electrical energy to the device [7].

Sunlight is often deemed as the only abundant and truly "free" energy resource. Among all the different tech- niques available to harness solar energy, the most popular and mature technology is the photovoltaic conversion of sunlight into electricity. Despite its merits, solar PV technology has issues with the land requirement (espe- cially in urban areas), capture efficiency and public perception (due to the absence of pleasing aesthetics). The concept of a solar tree is capable of addressing these problems effectively with elegance. In this paper an attempt is made to review the components of the solar tree and its design. The various commercial designs are also discussed along with applications of the solar tree. The paper also addresses the challenges involved with this technology and suggests future research direction [5]

Monocyrstalline silicon is a single crystal silicon in it. Solar cells with this type are the most efficient when compared to the two types of solar cells above. However, the weather is not bright can cause this type of solar cell to decrease drastically. Polycrystalline silicon / multicrystalline silicon is inversely proportional to monocrystalline silicon. This type of solar cell efficiency level is indeed lower than the monocrystalline silicon type, but can work better in a cloudy (not bright) state. Polycrystalline silicon has a random crystal arrangement. Random crystal arrangement has a lower usage period than a single crystal arrangement. [9]. The design design of power plants with solar cells without using the aid of a solar light tracking device seems to have not been studied again. Especially in Indonesia, this solar cell is widely used as a provider of electrical energy for traffic lights. The design of the placement of solar cells installed only leads to one place. Therefore, in this design the author makes the design of solar 
cell electric energy generator with the "Solar Tree" model. Like a tree, even though the sun rotates from east to west, tree leaves (solar panels) will always be illuminated by sunlight both morning, afternoon and evening.

\section{METHOD}

Parameters that affect the work of solar power systems:

a. Temperature

The temperature of the solar panel greatly affects the work of the solar panel itself. Where every solar panel manufacturer has also determined the Operating Temperature (NOCT), where in the NOCT conditions that have been determined this is a condition where solar panels can work optimally. The higher the temperature in the solar panel (exceeding NOCT), the solar panel will decrease.

b. Light intensity

Solar panel work will tend to decrease with the decrease in sunlight intensity. However, manufacturers of solar panels do not include a factor in reducing the efficiency of solar panels at a certain level of light intensity.

c. Air Humidity

In general, air humidity means the moisture content in the air. The moisture content changes according to the temperature, the higher the temperature, the higher the moisture content in the air.

Where air humidity is divided into 2 more specific parts, namely:

- Absolute humidity is the mass of water vapor at a certain volume and has a unit of grams per cubic meter (g/ m3).

- Relative Humidity (K) which is the value of ina percent of the ratio of the amount of water vapor contained in air at a certain temperature $(\mathrm{T})$ and the maximum amount of water that can be contained in air $(\mathrm{P})$.

$$
\mathrm{K}=(\mathrm{T} / \mathrm{P}) \times 100 \%
$$

d. Wind velocity

Wind speed also affects the temperature of the solar panel. And the temperature itself also has a big influence on the work of solar panels. So indirectly the wind speed also has an influence on the work of a solar panel.[10]

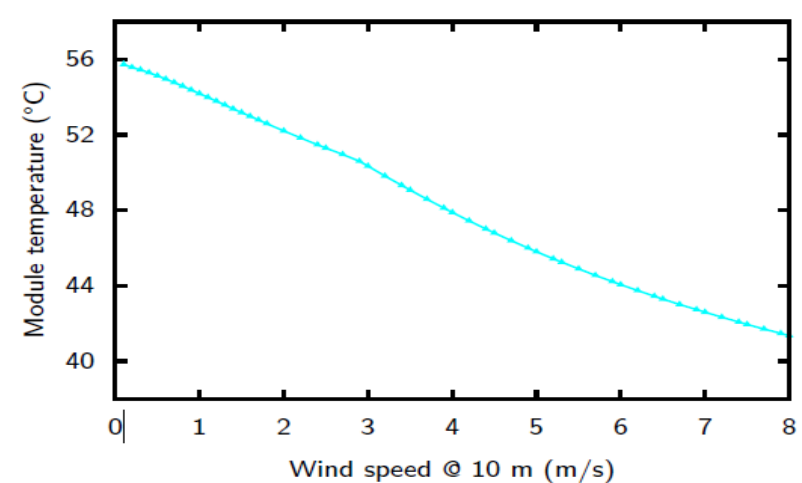

Fig. 2. Effect of wind on the temperature of solar panels with a fixed radiation condition of $1000 \mathrm{~W} / \mathrm{m}^{2}$ and an ambient temperature of $25^{\circ} \mathrm{C}$ on a clear day

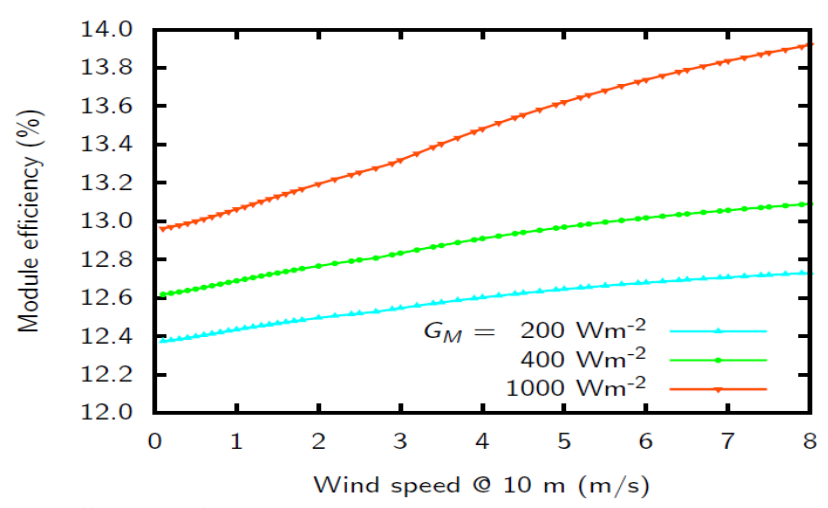

Fig. 3. Efficiency of solar panels with variations in solar radiation levels and variations in wind speed levels

\section{Design of solar cell power plant Solar Tree construction}

Currently there is a lot of research on solar trees. Increasing the output power of the solar panel will automatically require a large solar panel. But this can be dealt with by constructions such as the shape of a tree (solar tree). The design of the solar tree is made on the basis of the sun's angle to the earth. [12]

This type of construction is based on trees with photosynthetic leaves to produce nutrients for the tree. The main pillar is likened to the main stem of the tree. Branching support poles are likened to tree branches. And the solar panels installed on the support poles are likened to leaves. This solar panel (leaf) is responsible for absorbing sunlight and converting it into electrical energy.

Solar tree construction works more efficiently when compared to conventional fixed array construction. In addition, it is also more space efficient because it does not require extensive land such as on the roof of the house or the roof of the parking area. [13]. 

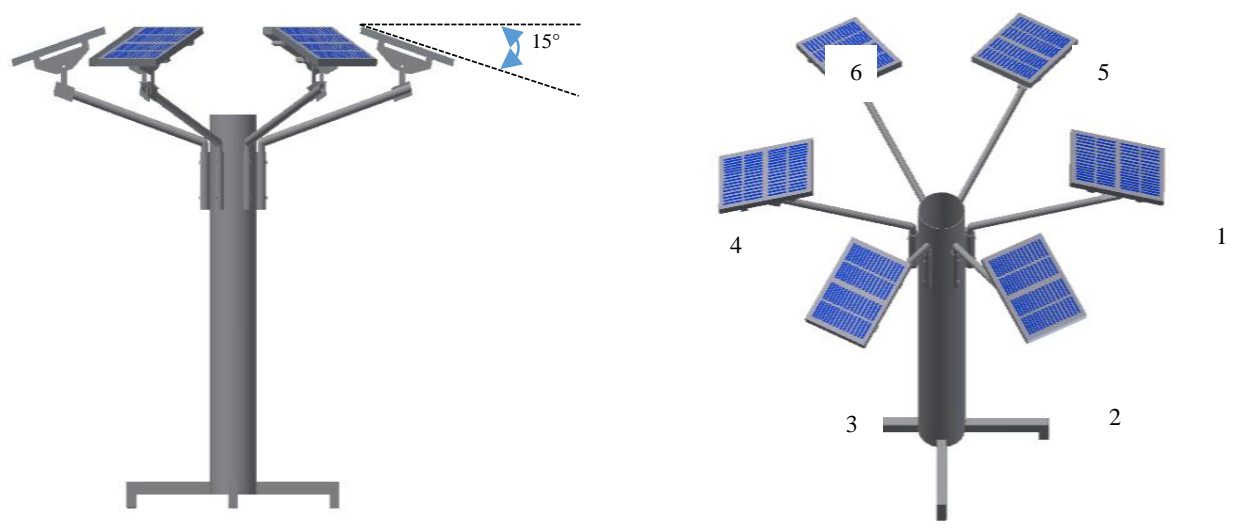

North

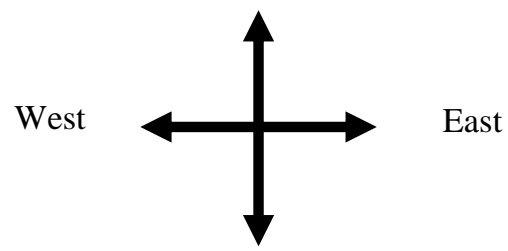

South

Fig. 4. Design of Solar Tree Design
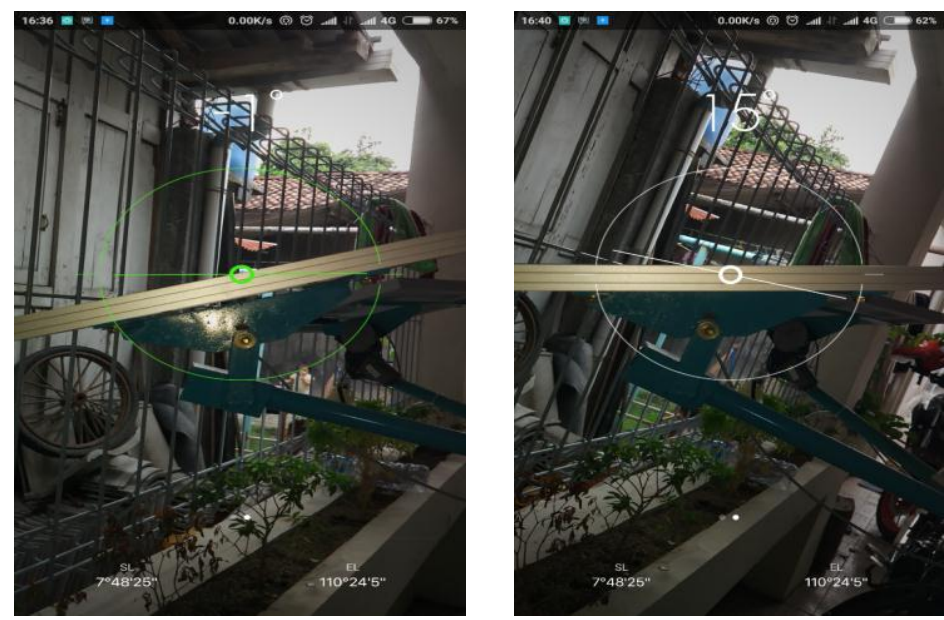

Fig. 5. Installing the Solar Panel on the Stand at a $15^{\circ}$

3. Testing the Angular Effect of the Solar Cell Output

In this study testing the sensitivity of LDR to sunlight, which causes changes in the solar cell angle. This aims to determine the optimal solar cell angle to absorb sunlight and provide maximum output. The method of testing and receiving sunlight in the solar cell is done as follows: 

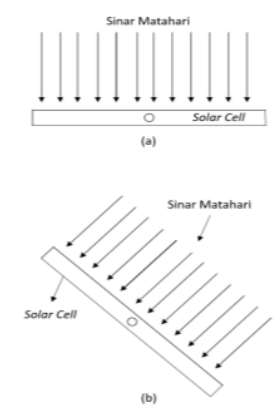

Fig. 6. Testing the effect of the direction of the solar angle on the output of the solar cell (a) the direction of the beam perpendicular to the panel (b) the direction of the beam forms a certain angle

\section{RESULT AND DISCUSSION}

\section{Open Circuit Voltage Testing (VOC)}

Open circuit voltage testing (Voc) is carried out on each solar panel individually. This Voc value is closely related to the value of sunlight intensity that can reach the surface of the solar panel. Here the light intensity is not measured because there is no tool to measure the intensity of sunlight and is represented by "weather".

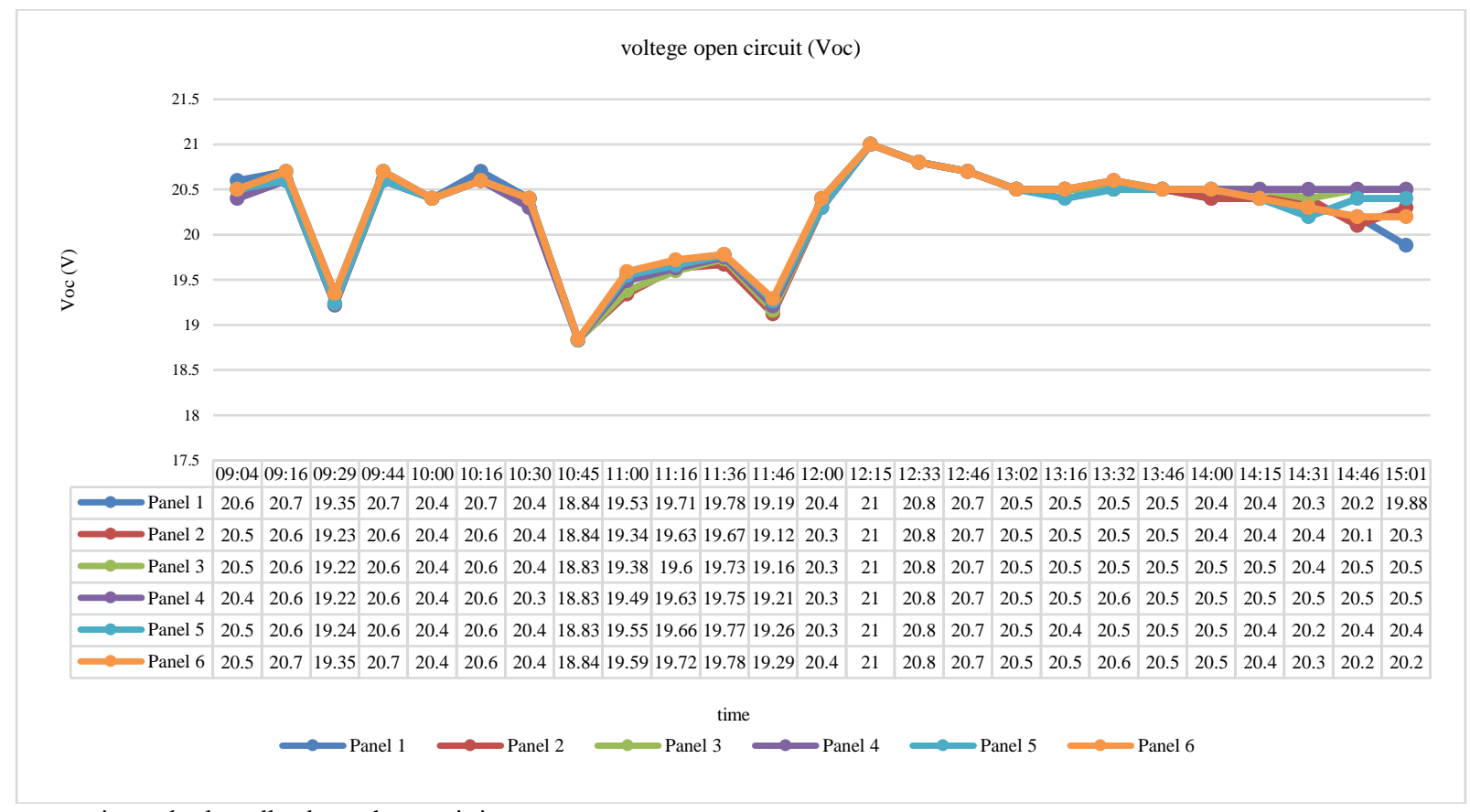

Fig. 7. Open curcuit panel solar cell voltage characteristics

In Figure 7. it can be seen that the open circuit voltage values on panels 1 to 6 appear to vary for data collection in the morning between 09 and 10.45 open circuit voltage ranges from 20 - 20.7 volts,

At 11.00 - 11.46 the location of the clouds tends to change according to the erratic wind direction, so the Voc value of each panel tends to change rapidly.
At 12:15 the Voc value on each panel reaches its peak with a value of $21 \mathrm{~V}$ because the position of the sun is right above the solar panel. Voc value starts to fall at 12.33. However, the Voc value for all solar panels is still the same until 13.02.

Meanwhile at 14.15 - 15.00, panel 4 and panel 3 have the highest Voc value (20.5 V) while the other solar panels slowly begin to drop its Voc value. 


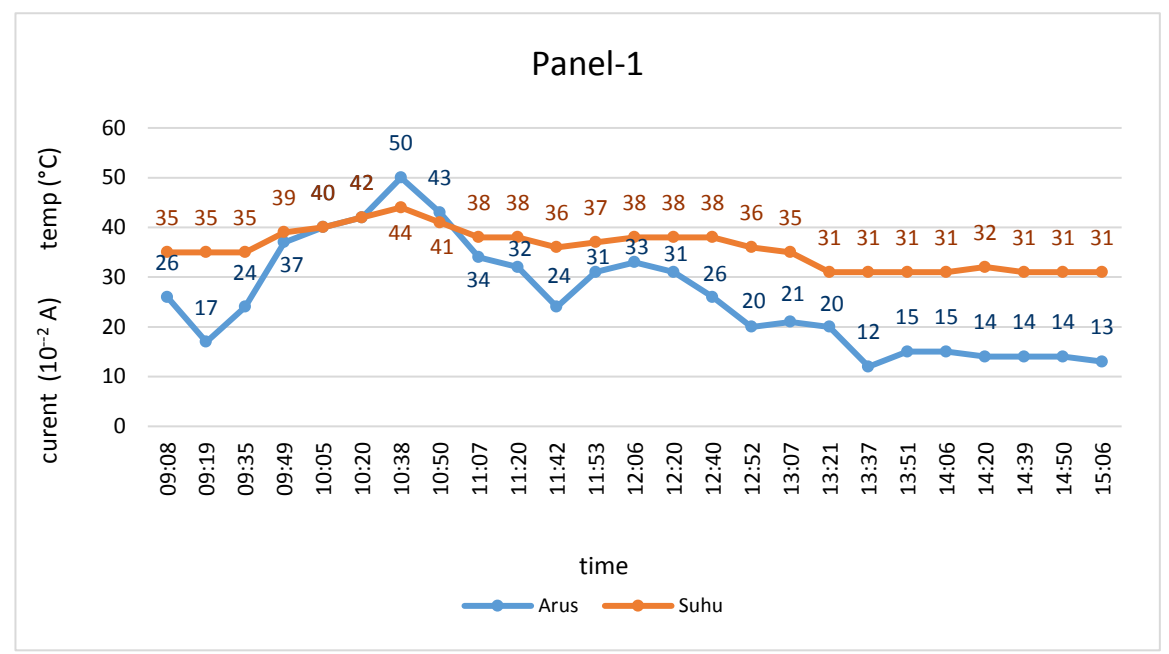

Fig. 8. Characteristics of load current to temperature

Panel-1 (load 10W)

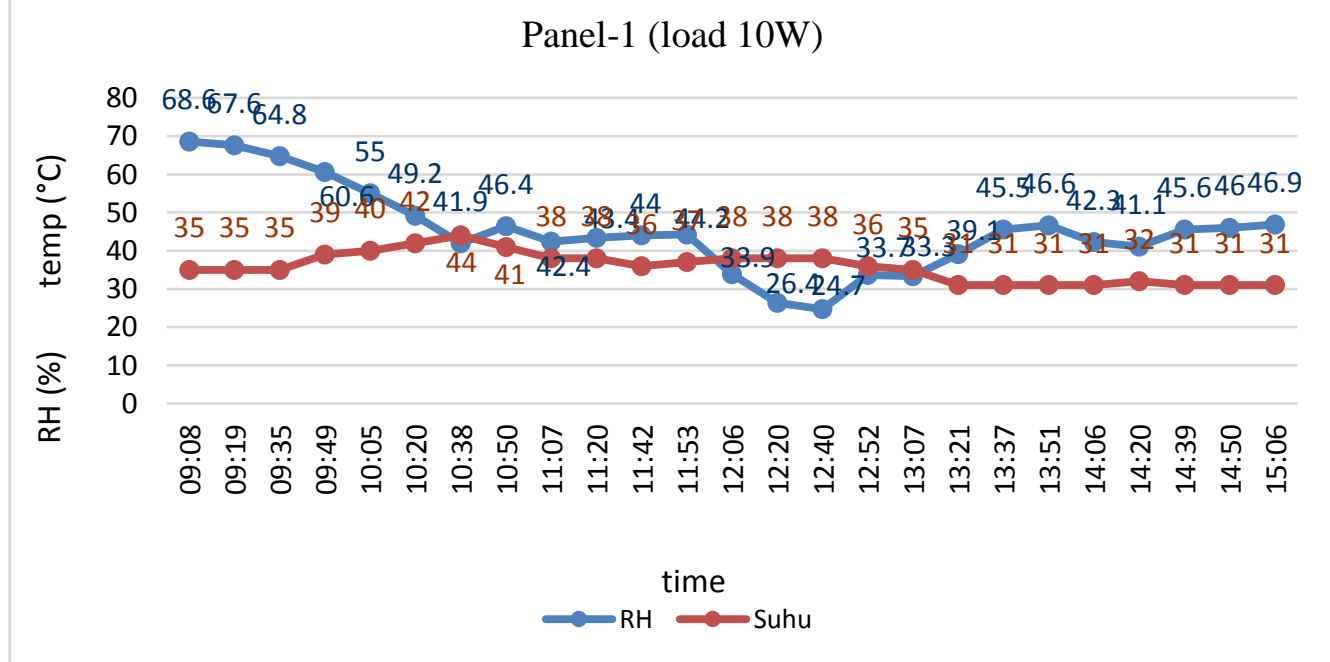

Fig. 9. Temperature characteristics of humidity

In Figure 8 shows the characteristics of the increase in load current to temperature in the solar panel here is the example on panel 1 with a load of $10 \mathrm{w}$. shows that the variable increase and decrease in current at a load of $10 \mathrm{w}$, follows the temperature increase and decrease variables in the solar panel.

In Figure 9 shows that the humidity factor does not affect the temperature in the panel seen in Figure 9 shows the humidity value varies greatly over time while the temperature value on the panel can be said to be relatively stable.

Meanwhile, looking at the graph of current and temperature comparison above, the current value is directly proportional to the temperature if the weather conditions are always bright. If there is a cloudy or cloudy condition that lasts fast, then the current value will not be directly proportional to the temperature, because the current value will drop rapidly according to the intensity of sunlight, but the value of the temperature will drop slowly. This causes the temperature value not directly proportional to the current value.
When the temperature is at a value of $42^{\circ} \mathrm{C}-48^{\circ} \mathrm{C}$, the panel can produce currents of $0.5 \mathrm{~A}$ to $0.6 \mathrm{~A}$ depending on the amount of sunlight intensity.

\section{CONCLUSION}

From the data presented, it can be concluded that at 09.00 10.36 panel 1 , panel 2, and panel 6 work more effectively compared to panel 3, panel 4, and panel 5. While at 13.33 15.03, panel 3, panel 4, and panel 5 work more effectively than panel 1, panel 2, and panel 6 , the humidity factor does not significantly influence the temperature value on the panel, the weather brightness factor is very influential on the temperature of the solar panel and also affects the current value produced by solar panels. 


\section{REFERENCES}

[1] E. Adityawan, Studi Karakteristik Pencatuan Solar Cell Terhadap Kapasitas Sistem Penyimpanan Energi Baterai. Depok: Universitas Indonesia, 2010

[2] A.S. Sarkin and T. Dindar, "The Effect of Latitude Differences, Sunshine Periods, Solar Radiation Quantities and Air Temperatures on Solar Electricity Generation, IJSGET," Transaction on Smart Grid and Sustainable Energy, vol. 1, no. 1, may 2017.

[3] A. Dadhic and D. Patidar, "Solar Tree in Daily Life," SSRG Int. J. Electro. Commun. Eng. (SSRG-IJECE) - vol. 3, Issue 5, May 2016.

[4] M.D. Patil and S.R. Madiwal, "Design and development of solar Tree for domestic application,” Int. J. Eng. Sci. \& Res. Tech. (IJESRT), August, 2016.

[5] F. Hyder, K. Sudhakar, and R. Mamat, "Solar PV tree design: A review," Renewable and Sustainable Energ. Rev. vol. 82, pp. 1079-1096, 2018.

[6] S. Roberts, Solar Electricity: A Practical Guide to Designing and Installing Small Photovoltaic Systems. Prentice Hall International: Cambridge, UK, 1991.
[7] T. Markvart. Solar Electricity: Second Edition. John Wiley \& Sons: Chichester, 2000.

[8] D.L. Pangestuningtyas, Hermawan, and Karnoto. Analisis Pengaruh Sudut Kemiringan Panel Surya Terhadap Radiasi Matahari Yang Diterima Oleh Panel Surya Tipe Array Tetap. Jurusan Teknik Elektro, Fakultas Teknik, UNDIP: Semarang., 2013

[9] K. Jäger, O. Isabella, A.H.M. Smets, R.A.C.M.M. van Swaaij, dan M. Zeman, "Solar Energy: Fundamentals, Technology, and Systems," Delft University of Technology: Netherlands, 2014.

[10] C. Bhuvaneswari, R. Rajeswari, C. Kalaiarasan, dan K.M.S Muthukumararajaguru, "Idea to Design a Solar Tree Using Nanowire Solar Cells,” Int. J. Sci. Res. Publ., vol. 3, Issue 12, December 2013.

[11] S. Tamimi, W. Indrasari, dan B.H. Iswanto, "Optimasi Sudut Kemiringan Panel Surya pada Prototipe Sistem Penjejak Matahari Aktif,” Prosiding Seminar Nasional Fisika (E-Journal), vol. V, October 2016.

[12] A.P.R. Srinivas, "Design and Development of a Solar Tree," Int. J. Sci. Eng. Res. (IJSER), vol. 7, Issue 10, October 2016.

[13] K. Vibhute and R. Shukla, "Economic Electrification Using Solar Tree," Int. J. Sci. Eng. Tech. Res. (IJSETR), vol. 4, Issue 6, June 2015. 